\title{
The Impacts of Emotional Intelligence Enhancement on Iranian Intermediate EFL learners Writing Skill
}

\section{Mohammad Reza Ebrahimi}

$\mathrm{Ph}$. D. Candidate, Chabahar Maritime University, Iran, rezaebrahimi2@yahoo.com

\section{Hooshang Khoshsima}

Assoc. Prof., corresponding author, Language Department, Chabahar Maritime University, Iran, khoshsima@cmu.ac.ir

\section{Esmail Zare-Behtash}

Assoc. Prof., Language Department, Chabahar Maritime University, Iran, behtash@cmu.ac.ir Emotional Intelligence on writing skill. The method of doing the study was giving an "Interchange Placement Test" to the university students who majored in English (EFL learners) in Iran. After selecting intermediate level students for participating in the study, an IELTS test was administered to evaluate the proficiency of the participants at the beginning of the project. Next, the Emotional Quotient (EQ) of the subjects was measured and afterwards, teaching Emotional Intelligence (EI) was started. At the end of a one-educational-year course of simultaneously teaching EI and writing skill, the same EQ and IELTS test was given to the learners. The difference in scores of both EQ and IELTS test were statistically calculated to observe the progress in each issue. The results revealed a significant change both in EQ and in writing skill. The findings of the study could help further the knowledge in the related field.

Keywords: emotional intelligence, writing skill, EFL learner, emotional intelligence enhancement, emotional quotient

\section{INTRODUCTION}

Every step of learning a second language could be difficult for some learners and relatively easy for some others. This difference in language learning is called language aptitude differences (Dornyei, 2006). But what exactly underlies aptitude is a very controversial issue in the literature (see Doughty, 2014). Thus, Language learning is an activity which depends on many factors but it is obviously dependent on the brain and more narrowly, intelligence.

Citation: Ebrahimi, M. R., Khoshsima, H., \& Zare-Behtash, E. (2018). The Impacts of Emotional Intelligence Enhancement on Iranian Intermediate EFL learners Writing Skill. International Journal of Instruction, 11(1), 437-452. https://doi.org/10.12973/iji.2018.11130a 
To measure intelligence, Intelligence Quotient (IQ) was applied early in $20^{\text {th }}$ century. Alfred Binett, a French psychologist was one of the greatest figures in modern intelligence testing movement. He collaborated on devising a measure for evaluating children's mental age (Mayers, 1998). Later some studies linked IQ to the potential for success (Weschler, 1958) and also with leadership success (Lord, Devader, \& Alliger, 1986). Insofar as not taking into account some factors like environment and culture, these measures were criticized and challenged on their validity (Riggio, Murphy, \& Pirozzolo, 2002). But nowadays, it is believed that IQ is not the only factor involved in success of an individual. There could be found some other parameters such as Emotional Intelligence (EI). Davis (2004) argued that whereas IQ affords the floor for accomplishments, EQ determines the 'ceiling' - that is, how high one can rise compared to others with the same cognitive and technical skills (p. 12). IQ contributes to approximately $20 \%$ of success and the remaining $80 \%$ could be assigned to other factors (Hunter \& Hunter, 1984; Schmidt \& Hunter, 1981). As Goleman (2005) argued EQ does the lion's share of achievement. To be more accurate, he stated that cognitive intelligence affords merely $20 \%$ of success and the rest is attributable to the skills and emotional intelligence; though it must be also noted that Goleman (2005, p. xiii) wrote that others who supposed that EI predicts huge proportions of achievement had misinterpreted his 1995 book. Despite some controversies on the role of EQ in success, it could be argued that all in all, EQ is a key factor in success, yet the intensity of effectiveness and efficiency varies according to different theories. Therefore, it is safe to conclude that IQ and EQ are important factors for success, more narrowly success in language learning and teaching, so the current study tried to experimentally add evidence to the role of $\mathrm{EQ}$ in success.

\section{Emotional Intelligence}

EQ has been defined in many different terms by many researchers in the field. The definitions almost overlap, but there are also differences. It was described as the ability to recognize, understand, adjust, and harness emotions (Salovey \& Mayer, 1990; Schutte, et al., 1998). Emotional intelligence can be defined as the ability to monitor one's own and other people's emotions, to discriminate between different emotions and label them appropriately and to use emotional information to guide thinking and behavior. Emotional intelligence also reflects abilities to join intelligence, empathy and emotions to enhance thought and understanding of interpersonal dynamics. However, controversies exist regarding the definition of $\mathrm{EQ}$, considering terminology and also operationalizations.

Emotional intelligence is defined as the awareness of an individual of his emotions and other's emotions and the ability to recognize and control them and also the ability to express sympathy for others. EQ deals with evaluating aspects of a situation (positive or negative) and making suitable solutions in stressful situations (Mayer, Salovey, \& Caruso, 2004). Accordingly, EQ is the ability to recognize emotions, to access and generate them in order to aid thought, to comprehend emotions and emotional knowledge, and to reflectively control them to advance emotional and intellectual growth (Mayer \& Salovey, 1997). 'EQ is the ability to monitor one's own and other's 
feelings, to differentiate among them and to utilize this information to direct one's thinking and actions' (Salovey \& Mayer, 1990). Emotional intelligence concerns the process of one's appraisal of his own and others' emotions, expressing feelings appropriately, processing emotional information and regulation of emotions to make the life better (Bown \& White, 2010; Ghanadi \& Ketabi, 2014; Razavi, 2014; Salovey \& Mayer, 1990).

Bar-On (1997) explains EQ as a series of non-cognitive abilities, competencies and skills that influence an individual's level of adaptability to the demands and pressures of the environment. According to him, emotional intelligence may be divided into five categories, respectively: intrapersonal (emotional self-awareness, assertiveness, selfesteem, self-actualization and independence), interpersonal (empathy, interpersonal relationships and social responsibility), adaptability (problem solving, reality testing, and flexibility), stress management (stress tolerance, impulse control) and general mood (happiness and optimism ).There are three main models of EQ: Ability model, Trait model, Mixed model (usually subsumed under trait EQ).

\section{EI and its Influence in Various Fields}

Jenkins, Oatley and Stein (1998), claimed that emotions are central to human life. EI could be listed among one of the most important known and investigated affective concepts which is increasingly attracting attention. It has been found that EI is very influential in successful learning (p. 136). With the development of humanism educators started paying attention to the learners' affective factors such as interests, feelings, emotions, confidence, etc. that learners bring to the class (Po-Ying, 2006). For example, foreign language anxiety was checked by Chao (2003) to see if there is any relationship between it and EI among EFL private college students in Taiwan. The findings of his study on 306 learners showed a significant link between EI as a whole factor and foreign language anxiety. Thus, it could be claimed that emotions are influential on language learning. Various areas of human life including achievement and more narrowly language achievement are dependent on social intelligence, and more specifically on emotional intelligence. There is a burgeoning amount of research (e.g.: Alavinia \& Agha Alikhani, 2014; Fahim \& Pishghadam, 2007; López, 2011; Pishghadam, 2009) which found that emotional intelligence has a say in various areas of language achievement.

\section{EI and its relationship with Success, Achievement, and Learning}

Goleman's first publication on EQ claimed that EI could be as powerful and sometimes more powerful than IQ (Goleman, 1995, P: 34). Motivation to learn an L2 and consequently being successful in it was found to be significantly and positively correlated with EI in the study of Alavinia, Bonyadi, and Razavi (2012). In the same line of inquiry, Fahim and Pishghadam (2007) faced the same results in the relationship between emotional intelligence, skills and academic success.

There is a considerable body of evidence which suggests that EQ has a positive impact on student's academic success (Abdullah et al. 2004; Parker et al. 2004a, 2004b); Mayer and Salovey (1997) suggested that general intelligence accounts for almost 10 to 20 percent of success. Regarding its say in academic settings and more particularly in the 
realm of language education, there is considerable interest in figuring out whether individual difference measures (other than intelligence) predict academic success. A sizable literature on this issue indicated links between personality and other traits and academic success. As an example, Parker et al. (2004) in a research examining the transition from high school to university, also found that various EQ dimensions predicted academic success. More recently, a small body of empirical research has emerged to indicate that EQ is not unrelated to academic achievement. Petrides, Frederickson, and Furnham (2004) investigated the relationships among EQ, cognitive ability, and academic performance with 650 participants. They figured out that EQ moderated the relationship between cognitive ability and academic performance. Also, there are studies on relationships between EQ and other important skills such as job performance.

\section{EI and Language Learning}

Language learning has turned as both necessary and inevitable in the life of at least academicians in the interdependent world. EQ as a probable influential factor in language testing in the world of language education is the focus of the current study since although there is substantial EQ research done in the workplace or on individuals, it needs more attention in education (Hargreaves, 2000; Pekrun and Frese, 1992). "Despite burgeoning research interest in the role of affect in psychological development, emotions experienced in the academic domain have until recently remained a largely unexplored field of psychological research" (Goetz T. et al. 2007, p. 3). Emotions also influence motivation, activation of learning resources, choice of learning strategies (cognitive and metacognitive), and thus on ultimate achievement. Cherniss (2000) claimed that teaching programs seeking development of EI in different areas could be employed. Management, communication and empathy training, stress management and conflict resolution will be improved in his findings through teaching EQ.

Many SLA researchers (MacIntyre, MacKinnon, \& Clément, 2009; Dörnyei, 2005; Imai, 2010; López, 2011) argue that foreign language learning is emotionally driven. EFL learners are susceptible to involvement in a range of emotions and feelings throughout learning a foreign language. Riemer (2003) argues that EQ skills improve learning potential of foreign language acquisition. Meng and Wang (2006) also argue that language learning could be facilitated by positive emotions and it also improves language performance.

Foreign language learners' achievement was also investigated by Shahmohamadi and Hasanzadeh (2011) to examine whether it is related to EI in Iranian context. The participants were 111 High Intermediate language learners. They utilized Bar-on's Emotional Quotient Inventory. No significant relationship between emotional intelligence as a whole factor and language achievement could be found, yet some of the components of emotional intelligence, like intrapersonal and general mood and some subcomponents (i.e., independence, self-assertion, and optimism) were statistically significantly related to language achievement. Two components of emotional intelligence, intrapersonal and interpersonal, could predict language achievement. 


\section{EI, Writing Skill and Vocabulary Learning}

EI is about intelligent use of emotions and utilizing the power or information contained in emotion to make effective decisions (Ciarrochi \& Mayer, 2007). In a seminal text entitled The Psychology of Writing: The Affective Experience (Brand, A. 1989) it was theorized for the first time that emotions impact the writing process of novices and professionals in a like manner and also the amount of it was discussed. Brand asserts that without an emotional component a theory of the writing process would be incomplete: He argues that without emotion the writing process is incomplete, bereft of any human points! From the beginning and during the tiresome course of writing and revising and drafting, emotions accompany writers.

Pishghadam (2009) investigated the effect of emotional and verbal intelligence on English language success in Iran. Pishghadam analyzed both the product and process data. The result of the product-based phase revealed that emotional intelligence is instrumental in learning various skills, particularly, productive ones.

Asadollahfam et al. (2012) studied the link between EI and vocabulary knowledge in language learners. 50 EFL learners were the participants at a university in Iran. Nation's (2001) Word Level Test was utilized to assess language learners' vocabulary knowledge and Bar-On's (1997) EI Questionnaire to assess their emotional intelligence score. The findings revealed that language learners with high levels of EI had a high level of vocabulary knowledge. Provided that it is accepted that EQ is important in different areas, what can be done regarding language earning? The current study is after including EQ and also enhancing it in language learning settings in an applied way. Now, it must be examined that EQ is apt to change or not?

\section{Is EQ Educable?}

The literature on emotional intelligence shows that EQ can be improved by systematic instructions. There is evidence that EQ can be enhanced and learnt through appropriate learning interventions and trainings (Goleman, 1995; Mayer et al. 1999; Jaeger, 2003; Bar-On. 1997). Gardner (1983) argued that social intelligence (which embraces EQ) is dynamic.

Some years later, Goleman (1995) argued that EQ is apt to change and those who have lower EQ could improve their abilities to identify, express, and regulate emotions. BarOn (1997), also suggested that EQ continues to develop with age and maturity and therefore can be developed. There are studies which prove such a notion. A study by Sala (2000) showed an improvement of the EQ level of individuals who had participated in the training programs. Slaski and Cartwright (2002) also proved a significant change in the EQ of experimental group after 4 weeks of receiving instructions. Some longitudinal studies also support these findings (eg: Kagan, 1998; Vaillant, 2000). Finally, school-based programs of emotional learning demonstrated similar results (Kusche \& Greenberg, 2001). Based on these findings, it could be concluded that EQ enhancement is not impossible. Educational strategies directed toward students' emotions improves academic performance (Pool, 1997). This finding resulted in many educational settings to execute school-based programs for improving emotional learning (SEL). The SEL program refers to the knowledge and skills that students acquire 
through emotional education, instruction or activities (Matthews et al. 2002). Topping et al. 2000) categorized the School-based EQ programs into seven typology interventions, namely "behavior analysis and modification interventions; counselling and therapeutic interventions; social skills training; peer-mediated interventions; cognitive and selfmanaged interventions; multiple interventions; and miscellaneous". The current study is trying to enhance EQ of a group of EFL students through a course on EQ while the learners are learning language and check the results. Writing skill is addressed in the current study, and the influence of teaching EQ on it was studied.

\section{METHOD}

The current research is a Quantitative study. "Quasi Experimental Study" design of the current co-relational study was administered by intact group sampling as follows. Questionnaires were used in the study both at the beginning of the experiment and at the end of the educational year which was the period that EQ was being taught to the students.

\section{Participants}

The participants of the study were all studying at the same university (Gonabad University, Iran). Students who study at the same university in Iran, have almost the same level of proficiency in English as they are placed based on a national university entrance exam. However, for reaching a more accurate assessment of the proficiency, students have been carefully selected based on the scores of "Interchange Placement Test" administered by the authors at the beginning of the project.

The participants were 43 intermediate EFL learners, which have been selected from among 56 EFL learners to ensure that there were no outliers among the participants. The profile of the learners goes as follows: they were between 18 and 23 years old all of which were freshman. Out of 30 learners, 18 were females and 12 males in the experimental group. The control group was composed of 13 students $(7$ male and 6 female). The control group was composed of students who majored in literature while the experimental group majored in applied linguistics (i.e.: English teaching). Almost none of the students attended any conversation class except for regular English classes held in high school and junior high school, thus it could be safely claimed that the proficiency of the participants was not significantly different at the beginning of the project.

\section{Data Measurement}

This study utilized the Likert scale which is also termed a summated instrument scale (Coldwell \& Herbst, 2004). Each item in EQ questionnaire was allocated a score from 0 -5 , which means that the items can be summed and then they can produce a total score (Coldwell \& Herbst, 2004). The higher the total EQ scores, the stronger the emotional intelligence skills would be.

\section{Instruments}

For the purpose of the study, the "Bar-On EI" test and a standard and IELTS test were given to the students. For measuring EQ, Bar-On developed a 133-item self-report Emotional Intelligence scale. This test (the emotional quotient inventory EQ-I (offers an 
estimate of EQ including 5 major scales and 15 subscales (using a five-point Likert Scale ranging from 'Never' to 'Always'). In the current study, the Persian version of the test was applied. Dehshiri (2003) asserted that the Persian version of the test is both valid and reliable considering Iranian culture. Estimated via Cronbach's alpha, the total reliability of the questionnaire was 0.82 . Before measuring EQ, an IELTS test was given to the students to measure writing skill separately. Then EQ class started adjacent to their regular class in Conversation. At the end of the semester, the same IELTS test was given to the students as post test to measure their progress in writing skill and simultaneously their EQ was measured through the same questionnaire to examine whether their EQ has changed at all, or not.

\section{Data Collection}

The study was carried out at the state university of Gonabad, Khorasan-Razavi province in Iran during two semesters of one educational-year (2016-2017). Learners were first instructed on what is the project and what is supposed to be done. They were made acquainted with the questionnaire (the Bar-On EQ test), and the activities they would do to enhance their emotional intelligence and the advantages of EI to make them more willing to participate in the study. Then "Interchange Placement" test was administered to make sure that the proficiency level of the students is almost the same and there would be no outliers. After the evaluation of the answers few students who were very weak or advanced were eliminated from the study, and intermediate students were selected to participate in an IELTS test in order to measure their ability in writing skill. IELTS results on writing skill were scored by two raters in order to increase the interrater reliability of the scores; then, the average of two different scores was used as the writing score for each student. The results of IELTS test which was administered as pretest, almost confirmed the results of Interchange Placement test. Then students were given instruction on EQ, what it is and how we can make a change. Some sessions were assigned to making the learners familiar with emotional intelligence and then practice on that was started. The topics for writing assignments were chosen based on emotional issues like: "Anger and how to control it? Include in your essay: What do you do while you are angry? What makes you angry? What was the last time you got angry? What was the most extreme reaction you did in case of getting angry?"

And questions like the above-mentioned ones were assigned to learners as homework for other sessions. After writing about the topics which were mostly emotional ones, students were asked to discuss their feelings and experience inside the class and share their knowledge with the classmates. Beside this experimental group, a control group answered the same IELTS test as pretest and posttest in the same period of time. In order to increase the accuracy of the research, EQ questionnaires were filled by the participants in the control group both at the beginning of the semester and at the end. They also participated in the same "Interchange Placement Test" and IELTS test, both at the beginning and the end of the educational year. Thus, the study was done through enhancing EI in treatment group while measuring the progress in both EI and writing skill, and observing the progress of EI and writing skill in a similar classroom which is the control group and received no instruction on EI. The materials were selectively 
chosen from a manual of teaching EQ to the leaders and some changes and adaptations were made to gear the manual to students who will be the leaders of their own classroom as teachers. The title of the manual is "50 Activities for Developing Emotional Intelligence" written by Adele B. Lynn. As the author describes the book, it is a collection of activities perfect for skill-building on self-awareness and control, empathy, social expertness, personal influence, mastery of vision and more. A sample lesson extracted from the book (P: 229) is as follows:

\section{Picture Yourself}

EQ Target / Self-Awareness and Control

Empathy $\quad$ Social Expertness $\quad \boldsymbol{V}$ Personal Influence $\quad \boldsymbol{V}$ Mastery of Vision

\section{Objectives}

- To help participants prioritize their energy

- To help participants determine what actions could best further their vision

Estimated Time: $35-45$ minutes

Materials: Emotional Intelligence Exercise \#40

Uses: • Training workshops on leadership

Difficulty: Medium

\section{Coaching Tips for the Trainer}

If only there were enough hours in the day, then the teacher would have time to do everything necessary to further the vision. Of course, all teachers face difficult priorities and tasks competing for their attention. However, fueling the vision is essential. Teachers must have and demonstrate passion toward the vision every day. This exercise is aimed at helping teachers visualize themselves doing positive actions. Visualizing oneself in successful situations helps people to commit to goals and also helps motivate people. Those who visualize themselves taking positive steps to achieve their goals are more apt to act on the visualizations.

\section{Trainer's/Coach's Notes}

\begin{tabular}{lc} 
Trainer's/Coach's Notes & $\begin{array}{c}\text { Approximate } \\
\text { Time }\end{array}$ \\
\hline 1. Overview: Explain to the individual or group that visualizing is a powerful tool for \\
development. Tell the group that many great athletes use visualization to improve their skill. & 1 minute \\
\hline 2. Purpose: "The purpose of this exercise is to help you to picture yourself doing things that & \\
further your goals in the workplace. By using visualization, you will picture yourself taking & 2 minutes \\
positive actions that will serve to promote your vision with your employees. For example, if & 2 \\
you think that you need to stop to talk to people more frequently as you walk through the & \\
work area, visualizing this activity will help you remember to do so. Visualizing it will also & \\
help you to know what to say, how to say it, and to whom you want to speak. Visualization \\
serves as the mind's cue to take the action that was mentally rehearsed. \\
\hline 3. Give Directions: \\
A. Give the participant(s) Exercise \#40. \\
B. Instruct participants to visualize themselves having unlimited energy to do what is \\
required to move their goals forward.
\end{tabular}


C. Ask them to see themselves as a leader with unlimited energy and stamina.

D. Ask participants to state what they see themselves doing each day that they currently don't have time to do.

E. Ask participants to very clearly picture themselves doing things that are moving their work unit toward their goals.

F. Ask participants to write down what they pictured themselves doing during the visualization.

4. Debrief by asking the following questions:

A. What obstacles are holding you back from the actions you saw in your visualization?

B. What benefits would occur if you acted on the visualizations?

C. Who could help you overcome the obstacles?

\section{FINDINGS}

In order to analyse the relevant data in this experiment, the Statistical Package for Social Sciences (SPSS), version 22 was employed. The level of significance was set at 0.05 . Table 1 reveals descriptive statistics obtained from the control and experimental groups in EQ test at pre-test.

Table 1

Descriptive Statistics for the Control and Experimental Groups' Performance on EQ Test (Pre-test)

\begin{tabular}{lllllll}
\hline & Group & N & Minimum & Maximum & Mean & Std. Deviation \\
\hline Pretest (EQ) & Control & 13 & 317 & 377 & 450.61 & 55.44 \\
\hline & Experimental & 30 & 511 & 572 & 483.56 & 47.50 \\
\hline
\end{tabular}

To ensure the normality of the distribution of the two groups at pre-test, a KolmogorovSmirnov test was run. The results revealed that the distribution of scores was normal in each group at pre-test (Control: $\mathrm{N}=13$, Statistic $=.201, \mathrm{p}=.155$; Experimental: $\mathrm{N}=30$, Statistics $=.109, \mathrm{p}=.200)$. Therefore, the researcher decided to use parametric statistics. In doing so, to compare the mean scores of the two groups at the pre-test, an independent samples t-test was conducted. The results of independent samples t-test for the performance of the experimental and control groups at the pre-test of EQ revealed that there was no significant difference between the EQ mean scores of the two group at the beginning $(\mathrm{t}=-1.986, \mathrm{p}=.054)$.

Descriptive statistics obtained from the control and experimental groups for the writing skill at the beginning of the experiment is shown in Table 2.

Table 2

Descriptive Statistics for the Control and Experimental Groups' Performance on the Writing Test (Pre-test)

\begin{tabular}{lllllll}
\hline & Group & $\mathrm{N}$ & Minimum & Maximum & Mean & Std. Deviation \\
\hline Pre-Test (Writing) & Control & 13 & 3.25 & 4.5 & 3.88 & .36 \\
\hline & Experimental & 30 & 3.25 & 6 & 4.06 & .66 \\
\hline
\end{tabular}

The results of Kolmogorov-Smirnov revealed that the distribution of scores was normal in the control group $(\mathrm{N}=13$, Statistic $=.221, \mathrm{p}=.081)$; however, it was not normal in the experimental group at the pre-test $(\mathrm{N}=30$, Statistics $=.307, \mathrm{p}=.000)$. Therefore, nonparametric statistics was run. The results of Mann-Whitney Test for the performance of 
the experimental (Mean Rank= 20.38) and control (Mean Rank= 22.70) groups at the pre-test of the writing skill indicated that there was no significant difference between the mean scores of the two groups at the beginning $(U=174, p=.565)$.

Descriptive statistics obtained from the control and experimental groups for the writing skill at the post-test is shown in Table 3.

Table 3

Descriptive Statistics for the Control and Experimental Groups' Performance on Writing Test (Post-test)

\begin{tabular}{lllllll}
\hline & Group & $\mathrm{N}$ & Minimum & Maximum & Mean & Std. Deviation \\
\hline Post-test (Writing) & Control & 13 & 3 & 5 & 4.03 & .43 \\
\hline & Experimental & 30 & 3 & 8 & 5.67 & 1.19 \\
\hline
\end{tabular}

The results of Kolmogorov-Smirnov test revealed that the distribution of scores was not normal in the control group $(\mathrm{N}=13$, Statistic $=.388, \mathrm{p}=.000)$; however, it was normal in the experimental group at the post-test $(\mathrm{N}=30$, Statistic $=.153, \mathrm{p}=.072)$. Hence, the researchers employed non- parametric statistics. The results of Mann-Whitney Test for the performance of the experimental (Mean Rank= 26.93) and control (Mean Rank= 10.62) groups at the post-test of writing demonstrated a significant difference between the mean scores of the two groups $(\mathrm{U}=74, \mathrm{p}=.000)$.

Descriptive statistics obtained from the control and experimental groups' writing gain scores is shown in Table 4.

Table 4

Descriptive Statistics for the Control and Experimental Groups' Performance on the Writing Test (Gain Scores)

\begin{tabular}{lllllll}
\hline & Group & $\mathrm{N}$ & Minimum & Maximum & Mean & Std. Deviation \\
\hline Post-test (Writing) & Control & 13 & -.5 & .75 & .15 & .37 \\
\hline & Experimental & 30 & -2.75 & 3.25 & 1.6 & 1.39 \\
\hline
\end{tabular}

The results of Kolmogorov-Smirnov test revealed that the distribution of gain scores was normal in the control group $(\mathrm{N}=13$, Statistic $=.187, \mathrm{p}=.200)$; however, it was not normal in the experimental group $(\mathrm{N}=30$, Statistic $=.202, \mathrm{p}=.003)$. The results of Mann-Whitney Test for the performance of the experimental (Mean Rank= 27.17) and control (Mean Rank= 10.08) groups for the writing gain scores showed that there was a significant difference between the mean scores of the two groups $(U=40, p=.000)$.

\section{DISCUSSION}

The purpose of the study was to examine the effect of EQ enhancement on the progress of writing ability. It was previously proved that through teaching EQ, the emotional intelligence of the students could be increased (e.g. Goleman, 1995; Mayer et al. 1999; Jaeger, 2003; Bar-On. 1997). Based on that, it was hypothesized in the current study that writing about students' emotions and frequent use of emotional words in writing assignments via consciousness-raising upon their feelings can help them know their feelings and it consequently increasees their EQ. This kind of writing is supplementary to EQ courses. The results of this experimental study proved that both EQ and writing 
skill increased significantly while there was no significant change in control group in which no treatment was done. Students were being taught by the same teacher and used the same teaching materials. Thus it is safe to conclude that the significant difference in the progress of both EQ scores and writing scores are attributed to emotional intelligence enhancement.

The findings of the study are in agreement with the findings of some researchers like Goleman (1995), Mayer et al. (1999), Jaeger (2003) who proved that EQ is educable. In the current study, EQ was taught for one educational year course and the results displayed that in control group no significant change was observed while in treatment group the EQ of the participants was significantly enhanced. Bar-On (1997), also faced the same results and then suggested that EQ keeps up growing with age and maturity and therefore can be developed. Sala (2000) trained some participants on how to develop EQ in a training program and faced similar results with what the researchers of the current study encountered. 4 weeks of instructions by Slaski and Cartwright (2002) also caused a significant change in the EQ of experimental group which is in the same line with what happened for the present study. The longitudinal studies like those of Kagan, 1998; Vaillant, 2000 were confirmed by this study.

Regarding academic achievement Pool (1997) found progress in achievements and writing skill which is a part of academic achievements. Ghabanchi and Rastegar (2014), Salahi (1998), Aghasafari (2006), and Fahim and Pishghadam (2007) also found a correlation between EQ and academic success which was confirmed in the current study. Also the results of the current study confirmed other research investigating the relationship between vocabulary learning and EQ, some of which were enumerated in previous sections of the article.

Brand (1989) theorized that writing skill is dependent upon emptions from the beginning and during writing, revising and also drafting. The findings of the current study could bring practical evidence for the theory. In the current study, significant change has been measured in the writing skill of the EFL learners who participated in the EI enhancement course contrary to insignificant change which was observed in the control group who exactly received the same academic instructions and were taught by the same teacher.

\section{CONCLUSION}

As an educated guess researchers of the present study presumed that there could be a way to enhance EQ and through this increase, language in general can develop better because it is dependent on affective factors. EQ was taught and at the end of the experiment the results of the data analysis indicated a significant increase in both EQ and writing skill.

As it was not possible to have access to students with almost the same level of proficiency to teach EQ for one educational year, the sampling procedure was done based on "Intact Group" selection not random selection which could be a limitation of the study; replications of the study shall consider this limitation in order to reach a more generalizable result. The implications of the study are that first and for most, educational systems across the globe (especially in Iran) can pay more attention to the issue of EI 
and after due studies in the field and assuring of the generalizability of the results of the current study) by replication in different contexts with various participants) syllabus designers might reconsider the content of the existing syllabi. EQ can have room in new syllabi, regarding the influence of it on education. Secondly, it seems necessary to inform teachers and instructors in educational system of the influence of EQ, and thus making them informed of the role of EQ in education and success. Even if no change in syllabi would be approved, at least workshops on EQ for teachers or some in-service instructions seem to be fruitful.

\section{REFERENCES}

Abdullah, M. C., Elias, H., Mahyuddin, R., \& Uli, J. (2004). Emotional intelligence and academic achievement among Malaysian secondary students. Pakistan Journal of Psychological Research, 19(3-4), 105-121.

Aghasafari, M. (2006). On the relationship between emotional intelligence and language learning strategies (Unpublished master's thesis). Allameh Tabataba'i University, Iran.

Alavinia, P., \& Agha Alikhani, M. (2014). Willingness to communicate reappraised in the light of emotional intelligence and gender differences. Procedia - Social and Behavioral Sciences, 98, 143-152. http://doi.org/vqg.

Asadollahfam, H., Salimi, A., \& Mahmood Pashazadeh, F. (2012). Emotional intelligence, gender and vocabulary. Procedia - Social and Behavioral Sciences, 46, 833-837. http://dx.doi.org/10.1016/j.sbspro.2012.05.208.

Bar-On, R. (1997). Bar-On emotional quotient inventory (EQ-I): Technical manual. Toronto, Canada: Multi-Health Systems.

Binet, A. (1905). A propos la mesure de l' intelligence. L'Annee Psychol., 2, 411-465.

Bown, J., \& White, C. J. (2010). Affect in a self-regulatory framework for language learning. System, 38(3), 432-443. http://doi.org/d6ss2w.

Brand, A. G. (1989). The psychology of writing: The affective experience. New York: Greenwood.

Chao, C. (2003). Foreign language anxiety and emotional intelligence: A study of EFL students in Taiwan. Texas A \& M University-Kingsville. Retrieved from

http://ezproxy.lib.uh.edu/Login?URL=/docview/305244027?accountid=7107

Cherniss, C. (2000). Social and emotional competence in the workplace. In R. Bar-On \& J. Parker, The handbook of emotional intelligence. San Francisco: Jossey-Bass. pp. 43358.

Ciarrochi, J., \& Mayer, J. (2007). Applying emotional intelligence: A practitioners guide. NY: Psychology Press, Taylor \& Francis.

Coldwell, D., \& Herbst, F. (2004). Business research. Landsdowne: Juta and Co Ltd. 
Cote, S., \& Miners, C. T. H. (2006). Emotional intelligence, cognitive intelligence and job performance. Administrative Science Quarterly, 51(1), 1-28.

Davis, M., (2004). Test your EQ. London: Piatkus.

Dehshiri, R. (2003). The reliability and validity of EQ-I in Iran's context (Unpublished master's thesis). Allame Tabataba'i University, Tehran, Iran.

Dornyei, Z. (2006). Individual differences in second language acquisition. AILA Review, 19 (1), pp. 42-68.

Doughty, C. J. (2014). Assessing aptitude: The companion to language assessment. New York: John Wiley \& Sons.

Fahim, M., \& Pishghadam, R. (2007). On the role of emotional, psychometric, and verbal intelligences in the academic achievement of university students majoring in English language. Asian EFL Journal, 9, 240-253.

Ghabanchi, Z., \& Rastegar, R. E. (2014). The correlation of IQ and emotional intelligence with reading comprehension. Reading, 14(2), 135-144.

Ghanadi, Z., \& Ketabi, S. (2014). The relationship between emotional intelligence and learners' beliefs about language learning: Iranian advanced EFL learners in focus. Theory and Practice in Language Studies, 4(3), 518-523.

Goleman, D. (1995) (a). Emotional intelligence. New York: Bantam Books.

Goleman, D. (1995) (b). Emotional intelligence: Why it can matter more than IQ. London: Bloomsbury.

Goleman, D. (1998). Working with emotional intelligence. New York: Bantam Books.

Goleman, D., Boyatzis, R. E., \& McKee, A. (2002). Primal leadership: Realizing the power of emotional intelligence. Boston, MA: Harvard Business School Press.

Goleman, D. (1998). What makes a leader? Harvard Business Review, 76(6), 93-102.

Hargreaves, A. (2000). Mixed emotions: Teachers' perceptions of their interactions with students. Teaching and teacher education, 16(8), 811-826.

Hunter, J. E., \& Hunter, R. F. (1984).Validity and utility of alternative predictors of job performance. Psychological Bulletin, 96, 72-98.

Imai, Y. (2010). Emotions in SLA: New insights from collaborative learning for an EFL classroom. Modern Language Journal, 94(2), 278-292. http://doi.org/cqwt6x In R. J. Sternberg (Ed.), The handbook of intelligence (pp. 396-420). New York: Cambridge University Press.

Jaeger, A. J. (2003). Job competencies and the curriculum: An inquiry into emotional intelligence in graduate professional education. Research in Higher Education, 44(6), 615-639. doi:10.1023/A:1026119724265 
Jenkins, J. M., Oatley, K., \& Stein, N. L. (1998). History and culture. In J. M. Jenkins, K. Oately, \& N. L. Stein (Eds.), Human emotions: A reader (7-12). Massachusetts: Blackwell Publishers.

Kagan, J. (1998). Galen"s prophecy. Boulder, CO: Westview Press.

Kusche, C. A., \& Greenberg, M. T. (2001). PATHS in your classroom: Promoting emotional literacy and alleviating emotional distress. In J. Cohen (ed.), Caring classrooms/intelligent schools: The social emotional education of young children. New York, NY: Teachers College Press, pp. 140-161.

López, M. M. (2011). The motivational properties of emotions in foreign language learning. Colombian Applied Linguistics Journal, 13(2), 43-57.

Lord, R. G., DeVader, C. L., \& Alliger, G. M. (1986). A meta-analysis of the relationship between personality traits and leadership perceptions: An application of validity and generalization procedures. Journal of Applied Psychology, 71, 402-410.

MacIntyre, P. D., Mackinnon, S. P., \& Clément, R. (2009). The baby, the bathwater, and the future of language learning motivation research. In Z. Dörnyei \& E. Ushioda (Eds.), Motivation, language identity and the L2 self (pp. 43-65). Bristol, UK: Multilingual Matters.

Matthews, G., Zeidner, M., \& Roberts, R. D. (2002). Emotional intelligence: Science and myth. Bradford, Cambridge, MA.

Mayer, J. D., Caruso, D. R., \& Salovey, P. (1999). Emotional intelligence meets traditional standards for an intelligence. Intelligence, 27, 267-298.

Mayer, J. D., Salovey, P., \& Caruso, D. R. (2000). Models of emotional intelligence. In R. J. Strenberg (Ed.), Handbook of intelligence (pp. 396-420). New York: Cambridge University Press.

Mayer, J. D., Salovey, P., \& Caruso, D. R. (2002). Mayer-Salovey-Caruso emotional intelligence test: Manual. Toronto. Canada: Multi-Health Systems.

Mayer, J. D., Salovey, P., \& Caruso, D. R. (2004). Emotional intelligence: Theory, findings and implications. Psychological Inquiry, 15(3), $197-$ 215.doi:10.1207/s15327965pli1503_02.

Mayer, J. D., \& Salovey, P. (1997). What is emotional intelligence? In P. Salovey\& D. Sluyter (Eds.), Emotional development and emotional intelligence: Implications for educators (pp. 3-31). New York: Basic Books.

Mayer, J. D., Salovey, P., \& Caruso, D. (1998). Competing models of emotional intelligence. In R. J. Sternburg (Ed.), Handbook of human intelligence ( $2^{\text {nd }}$ ed.). New York: Cambridge University Press.

Mayer, J. D., Salovey, P., \& Caruso, D. (2002). MSCEIT user's manual. Toronto, ON: Multi-Health Systems. 
Mayer, J. D., Roberts, R. D, \& Barasade, S.G. (2008). Human abilities: Emotional intelligence. Annual Review of Psychology, 59, 507-536. doi:10.1146/annurev.psych.59.103006.093646.

Mayer, J. D., Salovey, P., Caruso, D. R., \& Sitarenios, G. (2003). Measuring emotional intelligence with the MSCEIT V2.0. Emotion 3, 97-105. doi:10.1037/15283542.3.1.97.

Mckenna, J., \& Webb, J. (2013). Emotional intelligence. British Journal of Occupational Therapy 76(12), 560.

Meng, X., \& Wang, Q. (2006). Psychological factors and teachers' language. Foreign Language Journal, 4(5), 70-73.

Parker D. A. J., Summerfeldt J. L., Hogan G. M., \& Majeski A. S. (2004). Emotional intelligence and academic success: Examining the transition from high school to university. Personality and Individual Differences, 36(1), 163-172.

Pekrun, R., \& Frese, M. (1992) Emotions in work and achievement. In C. L. Cooper and I. T. Robertson (Eds.), International review of industrial and organisational psychology, 7, pp. 153-200, Chichester, UK: Wiley

Petrides, K. V., Frederickson, N., \& Furnham, A. (2004). The role of trait emotional intelligence in academic performance and deviant behavior at school. Personality and Individual Differences, 36(2), 277-293.

Pishghadam, R. (2007). On the influence of emotional and verbal intelligences on second language learning (Unpublished doctoral dissertation). Allame Tabataba'ii University, Tehran, Iran.

Pishghadam, R. (2009). A quantitative analysis of the relationship between emotional intelligence and foreign language learning. ElectronicJournal of Foreign Language Teaching, 6(1), 31-41.

Pishghadam, R. (2009). Emotional and verbal intelligences in language learning. Iranian Journal of Language Studies, 3(1), 43-64.

Pool, C. R. (1997). Up with emotional health. Edu. Leader, 54, 12-14.

Po-Ying, L. (2006). Multiple intelligences theory and English language teaching. Retrieved from www.360doc.com/content/06/0513/22/3147_115405.shtml.

Razavi, R. (2014). EFL teachers' emotional intelligence and their personality types: Exploring possible relations. Advances in Language and Literary Studies, 5(2), 134 141. http://doi.org/vqj.

Riemer, M. J. (2003). The impact of emotional intelligence on communication in engineering education. Proceedings of the $6^{\text {th }}$ UICEE Annual Conference on Engineering Education, Cairns, Australia, pp. 203-206. 
Riggio, R. E., Murphy, S. E., \& Pirozzolo, F. J. (2002). Multiple Intelligence's and Leadership. Mahwah, N.J.: Lawrence Earlbaum Associates.

Rostampour, M., \& Niroomand, S. M. (2013). On the correlation between Iranian undergraduate EFL learners' emotional intelligence, motivation and vocabulary knowledge. International Journal of Language Learning and Applied Linguistics World, 4(4), 473-482.

Sala, F. (2000) Do programs designed to increase emotional intelligence at work-work? Boston, H/Mcber, pp. 1-6. EI program evaluation, Consortium for Research on Emotional Intelligence in Organizations. Retrieved from http://www.eiconsortium.org/pdf/mastering_emotional_intelligence_program_eval.pdf

Salahi, G. (1998). The effect of intelligence on the performance of EST students on reading comprehension (Unpublished master's thesis). University of Science and Technology, Tehran, Iran.

Salovey, P., \& Mayer, J. D. (1990). Emotional intelligence. Imagination, Cognition and Personality, 9, 185-211.

Schmidt, F. L., \& Hunter, J. B. (1981). Employment testing: Old theories and new research findings. American Psychologist, 36, 1128-1137.

Shahmohamadi, F., \& Hasanzadeh, R. (2011). Emotional intelligence and its predictive power in Iranian foreign language learners' language achievement. International Conference on Social Science and Humanity, 5, 1-5.

Shutte, N. S., Malouff, J. M., Hall, L. E., Haggerty, D. J., Cooper, J. T., Golden, C. J., \& Dornheim, L. (1998). Development and validation of a measure of emotional intelligence. Personality and Individual Differences, 25, 167-177.

Skourdi, S., \& Rahimi, A. (2010). The relationship of emotional intelligence and linguistic intelligence in acquiring vocabulary. California Linguistic Notes, 35(1), 2345 .

Slaski, M., \& Cartwright, S. (2002). Health, performance and emotional intelligence: An exploratory study of retail managers. Stress and Health, 18(2), 63-68.

Topping, K., Holmes, E. A., \& Bremner, W. (2000) The effectiveness of school-based programs for the promotion of social competence. In: Bar-On, R and Parker, J D A (Eds.) The handbook of emotional intelligence. San Francesco: Jossey-Bass. pp. 411432.

Vaillant, C. E. (2000). Adaptive mental mechanisms: Their role in a positive psychology. American Psychologist, 55, 89-98.

Wechsler, D. (1958). The measurement and appraisal of adult intelligence (4th ed.). Baltimore: Williams \& Wilkins.

Wechsler, D. (1997). Wechsler adult intelligence scale-third edition. San Antonio: The psychological corporation. 